\title{
IGFBP3 Gene
}

National Cancer Institute

\section{Source}

National Cancer Institute. IGFBP3 Gene. NCI Thesaurus. Code C24488.

This gene plays an inhibitory role in the regulation of extravascular tissue growth. 